\title{
Stoics and Epicureans for the 'Modern Market': How Athenian Educators Re-Tooled the Old City's 'Modernist Schools' for Republican Rome. One of a Trilogy of Studies in the Marketing of Athenian Education to a 'newer' Ancient World
}

\author{
By David P. Wick*
}

\begin{abstract}
After the crisis caused when Rome expelled Greek thinkers and teachers in 161 of the old era, the momentum Athens still held a destination for students from the Mediterranean west, and Rome in particular, lay mostly with the old schools whose names everyone recognized. It was the two more "modernist" schools of Athens - the self-defined scientists and life-gurus of the Epicurean "Garden" and the anthropology-driven philosophers and political thinkers of the Stoa that were most vulnerable to this assault. Today, we remember almost all the great leaders and thinkers of the late Roman Republic and the "Principate" empire it would rapidly become as Stoics, but it was the Epicurean "Garden" that began the last decades of the Republic both notorious and fashionable. Though Epicurus himself had argued that in stressful times like these the true study was of ways to harmonize or cure angst in the human soul, 1st Century Epicurean teachers split, teaching a spiritual science of contemplation and retreat, or chasing a sort of scientific, audience-based media expertise for power-hungry students. Modern classicists may associate the Stoic school with images of retired contemplation, harmony, even mysticism, but Romans of the Late Republic expected the Stoa to retail "no nonsense" political and anthropological expertise. What they found in an Athens weary of political turmoil was something more like our modern expectations of "career-practical" education. This sold poorly at first, but the prolonged effects of Civil War-weariness saved the Stoa, and made it the refuge of a generation of ruined political "players". Was it simply an accident of history that this clientele grew so quickly, or did the Stoa sense an opportunity? This overlooked Athenian success story is relevant to modern struggles in liberal arts education, as it faces thinking formed by economic crises and the short-term focus of politicians and managers created by those crises.
\end{abstract}

No modern study of competing colleges trying to survive and attract "trending" students in an age of change and financial challenge can provide many truly "new" elements in the dilemma that were not there when the ancient schools of Athens realized they must adapt quickly to the decline of the Hellenistic world, and the inexorable tug which pulled the Hellenic world in under the shadow of Rome.

Perhaps that is putting it too strongly, but in a series of studies presented here over recent years, the stories of the wildly mutating Platonic Akademe, and the transformation of Aristotle's Lyceum into an incubator of consultants and wandering "regional experts" may have made a pretty good case for aggressive statement.

After the crisis caused by Rome's expulsion of Greek thinkers and teachers in 161 of the old era, the momentum that remained to keep Athens a destination for students from the Mediterranean west, and Rome in particular, lay mostly

${ }^{*}$ Professor, Gordon College, USA. 
with the old schools whose names everyone recognized. Cato the Elder had been angered by a teacher from the Akademe, but he targeted the reputation of the Epicurean school in Athens to tar all the higher education of Athens with the brush of an over-clever, amoral, "scientifically degenerate" and (most importantly and most vaguely) "un-Roman," "un-western" influence on the young generation who would shape the Roman Republic.

It was the two more "modernist" schools of Athens - the self-defined scientists and life-gurus of the Epicurean "Garden" and the anthropology-driven philosophers and political thinkers of the Stoa that were most vulnerable to this assault. Today, we remember almost all the great leaders and thinkers of the late Roman Republic and the "Principate" empire it would rapidly become as Stoics (though Caesar and his assassin Cassius, the younger Cicero and his famous literary friend Atticus, even the dictator Sulla, were Epicurean by training). Clearly, the more modern of the Athenian 'colleges turned the tables on Cato the Elder and came to dominate the intellectual landscape that formed the young Roman political world before and during Caesar's day. This study, third in a series pursuing the survival of the Athenian schools in the Roman world of the late Republic, takes an initial look at this remarkable "win against the odds."

The Epicurean "Garden" began the last decades of the Republic both notorious and fashionable. By comparison with Aristotle's old liberal arts college (despite the reputations of both Aristotle and Theophrastus) the real scientists of Athens taught at the "Garden." The Epicurean schools were famous for a particular flavor of scientist - Epicureans were theoretical "logical positivists" (far more important than the quality of the school's food or drink). The typical Epicurean image was a caricature of the wise-clever intellectual who cocked a skeptical eyebrow, referred to laboratory tests, and debunked social myths, who would tell you for a fee that a proper understanding of your component atoms would cure your anxieties. These were what the English of a century ago called "Balliol men;" if young Romans of the late Republic were going to be taught by magistri Graeculi they didn't want clever theorists about science and human culture, they wanted men who knew the inside of Whitehall. Aristotle hadn't talked about ataraxia (the new Epicurean word for syndromes and stresses in the modern personality that required manipulative leadership), Aristotle had talked about balanced government. In the last decades of the Roman Republic, most of the young players in politics (and their hopeful families footing the bills) aimed instead the science of "spinning" government, not at its theory or balance.

\section{The "Garden"}

And yet, though Lucretius would eventually make it stylish, Athens' most scientific school got the slowest start in Rome. In 161 of the old era, Epicureans had been particularly singled out in the expulsion of Greek philosophers from Rome, though whether this would end in damaging the appeal of the Athenian 
"Garden" or give it the glitter of notoriety remained to be seen. ${ }^{1}$ The famous embassy of Athenian philosophers to Rome in 155 B.C. included Carneades representing the Academy, Critolaus the Lyceum, and Diogenes of Seleucia (the "Babylonian") the Stoa; there was no Epicurean. Neither, for the technical scholars of the era, was there an Epicurean listed in the ephebic honorary inscriptions of $123 / 22$ or $80 / 79$.

We might, consequently, be tempted to think once again of the cloud under which the less famous schools lay in the period of Athens' final transition to a Roman "finishing" culture, but this time Diogenes Laertius supplies us with a fairly secure line of succession for the "Garden" or school of Epicurus. After Basilides of Tyre (the Epicurean scholarch passed over in 155), the headship passed to Apollodorus of Athens, thence to Zeno of Sidon and Phaedrus of Athens (during and after the era of the Mithridatic siege), and finally in the 50 's to a student of Phaedrus known as Patro. ${ }^{2}$ Zeno and Phaedrus seem to have been contemporaries: Phaedrus the better liked of the two (and perhaps officially the "scholarch", ${ }^{3}$ and Zeno the more fiery and the more active lecturer. ${ }^{4}$

Phaedrus, a wealthy son of the Athenian aristocracy, ${ }^{5}$ appears to have been an Epicurean traditionalist, whose (at least overt) teaching that a cure to the tensions of life still required abstention from public business must have seemed very out of fashion in the last century of the Republic. ${ }^{6}$ Perhaps it also saved him from Sulla's vengeance after Aristion's hostage crisis and Sulla's siege in Athens failed to make a rebel of the city. It ought to be remembered that Mithridates' puppet in the later stages of the catastrophe had both claimed himself an Epicurean, and had behaved almost as a caricature of the "bad" Epicureans so out of favor in the west. It was once thought that Phaedrus also fled to Rome in about 90, but no real evidence for this exists. ${ }^{7}$ Cicero spoke of hearing early lectures from him in the company of Atticus, but this apparently refers to their time studying together in the Athens of 79, a full decade later, and with the feel that his teaching was a long-running attraction in town. ${ }^{8}$ Phaedrus must, on such evidence, have lasted a long while, becoming the favorite teacher of private-minded Roman Athenians like Atticus and his friend the amateur historian Saufeius, both of whom dedicated a statue to him in the city. ${ }^{9}$

1. Athenaeus xii, 68 .

2. Diogenes Laertius x, 25-26. J.-L. Ferrary, Philhellénisme et Impérialisme: Aspects Idéologiques de la Conquête Romaine du Monde Hellénistique, de la Seconde Guerre de Macédoine à la Guerre Contre Mithridate (Rome, 1988), 445-446. Rawson, Intellectual Life in the Late Republic (London, 1985), $445 \mathrm{ff}$.

3. Badian, "Rome, Athens, and Mithridates" in American Journal of Ancient History, vol. 1 (1976), 514.

4. Asconius, In Pison., 68. Ferrary, Philhellénisme, 445-446. Rawson, Intellectual Life in the Late Republic (London, 1985), p. 9, n. 30; 23.

5. Raubitschek, A.E. "Phaedros and his Roman Pupils" in Hesperia, (1949), p. 96 f.

6. Cicero, Ad Fam. XIII, i, 2; De Finibus i, 16. Rawson, Intellectual Life, p. 6, n. 14. Against this, Ferrary, 446, n. 39.

7. Badian, "Rome, Athens, and Mithridates," 514, and n. 44.

8. Cicero, Ad Att. XVI, vii, 4.

9. Cicero, De Finibus v, 3. 
Zeno of Sidon, on the other hand, seems to have thrived on controversy, and to have been available for lecture at the slightest hint. He figures prominently among the teachers Cicero and Atticus heard in 79, and taught the aspiring orator C. Aurelius Cotta as well. ${ }^{10}$ This last is significant: Epicurus had been extremely dubious about the value of rhetoric, as he had been about the value of culture and the persuasive sciences generally. ${ }^{11} \mathrm{He}$ reiterated in his Epistles that none of the sciences, so far as he could see, had the slightest value in harmonizing and curing the angst in the human psyche. Ataraxia - freedom from the turbulent emotions that tore humanity from within - was the goal of real life, not a transitory expertise in persuasion or political power. ${ }^{12}$ True "science" was the "zen" of internal harmony.

Phaedrus seems to have been comfortable with this position, and preached an attractive "Epicureanism of refuge," but to Zeno (as to Philo of Larissa) that left one unable to teach the skills precisely most saleable in an era of political adventure. He and his own student Philodemus of Gadara (who would become the great Epicurean apologist of Augustan Italy) tried to rebuild a techne of oratory - of political communications - along Epicurean lines of "calculable pleasure" (what we might today call "audience driven principles of media success" with political applications), to sell it in Athens and abroad, and to defend it against the almost immediate accusation of heresy from Epicureans in other centers like Rhodes. ${ }^{13}$

But Zeno, like some other more recent political scientists, was at his worst when he was truest to his principles. His "innovations" appear to have drawn derision from some of the other Athenian schools, especially from the Stoa. At some time during the 80's - perhaps during that brief, heady, and artificial fashion for Epicureanism caused by the regime of Aristion - Zeno seems to have grown so angry at the slurs of a Stoic named Theotimus that he paid to have him killed. ${ }^{14}$ Even in exile after the killing, Zeno seems to have retained popularity, at least with his partisans.

In the end, though, the Garden seems to have drawn only the most private among Athens' Greek and Roman students; we hear principally about its own festivals given in jovial memory of their founder -- their euergetes -- on the twentieth of every month, ${ }^{15}$ but not about any great draw or influence it had in the city. That it "sold", but sold unostentatiously, we may gather from the fact that Atticus and Saufeius were quietly given statues themselves by the city in thanks for their dedication to Epicurus. ${ }^{16}$ Epicurus had value in

10. Ferrary, 446, n. 37.

11. Epicurus, Epist. i, 79; ii, 85. Cf. Dodds (contra Farrington, who pressed the case of the "neo-scientist" Epicurus), Greeks and the Irrational (Berkeley: University of California Press, 1951), 248 f., 259, and 265 n. 77.

12. E.R. Dodds, ibid., 240.

13. E. Rawson, Intellectual Life (London, 1985), 144-145.

14. E. Badian, Studies in Greek and Roman History, (1964), 215 ff.

15. Cicero, De Finibus, V, i, 3 (esp. about Epicurean pictures and symbols on the rings and cups); Tusculans i, 48. D.M. Lewis, "Two Days," in Classical Review, (1969), 272. See Dodds, Greeks and the Irrational, 259, n.36 against Ferguson's view that commemorative worship of an "euergetes" (whether royal or philosophical) was merely pragmatic public ritual.

16. A. E. Raubitschek, "Phaedros and his Roman Pupils," in Hesperia, no. 18(1949). 96; Rawson, Intellectual Life, 9, n. 28. 
the new era not because he could be made another signpost under which to retail the skills of ambition or empire, but because he had promised peace and escape. The great Epicurean "players" of the era - Sulla, Caesar, Cassius, even Tiberius - all got their degrees from the Epicurean school on Rhodes.

To be the college of quiet and escape was not entirely an innovation for the Epicureans, though it played a fresh role in the newly secluded feel of Athens. Philosophers were already beginning to be primarily connected in the popular mind with the ability to suffer pain or injustice silently, and to live simply (anyone who wanted to play at being a philosopher began by adopting a "Spartan cloak"-like the one familiar from cheap fourth century figurines of Socrates). That a philosopher such as Epicurus could have lived so long, and so healthily, made him attractive as an oddity, a sort of "guru" of ataraxia.

And Epicurus had himself been in some part responsible for this new image of the philosopher as "guru." He taught his followers that they could live "like gods among men" (Epistolae iii, 135 - zéseis dè hos theòs en anthrópois; and Aelian, Variae Historiae, IV, 13). Epicureans met regularly, as we have seen, to commemorate him on the twentieth of each month, often in some old haunt associated with him and often with more than "philosophical" enthusiasm, referred to him as a god. ${ }^{17}$

It is then only a curious surprise to discover the Epicureans, not the Stoics of this era, developing a flair for writing heroic biographies of their notable followers that highlight illnesses suffered gently, and deaths bravely faced. ${ }^{18}$ The lasting appeal, as Phaedrus seems to have guessed better than Zeno, lay in cult and sanctuary, not in intellect. Dodds put it well:

"The Stoic contemplated the starry heavens, and read there the same rational and moral purpose which he discovered in his own breast; the Epicurean, in some ways the more spiritual of the two, contemplated the unseen gods who dwell remote in the intermundia and thereby found strength to approximate his life to theirs." 19

\section{The Stoa}

The images of intellectual contemplation or even of mystic retirement that classicists associate with the term "Stoic" might make it a surprise, but in the last century of the Roman Republic, the Athenian Stoa seemed the "no nonsense' choice for young, ambitious students with their eye on public success. The heritage of Polybius and the other teachers of the Italian

17. Lucretius V, 8 (see note 2 above). Something of this popular--and only semirational-- "guru-cult" of the philosopher may in fact be both early and authentically Greek (one thinks of Pythagoras, and perhaps Heracleitus), a willingness to worship "superhuman" clarity of mind. One cannot quite catch the essential old Greek hunger that made Plato's "Guardians" almost plausible without recreating some feel for it.

18. W. Cronert, "Der Epikurer Philonides," Sitzb. Berl. Ak., (1900), 942. Rawson, Intellectual Life, 294-295.

19. Dodds, Greeks and the Irrational, 240. 
"Scipionic" college of the late second century had created, in Italy, an authentic reputation for the Stoic school that centered around concrete political and even anthropolopgical study that had practical "career" value, but Romans arriving in Athens after the Mithridatic and Sullan crises would likely found themselves at a loss. If there were lectures, even on philosophy much less on politics, available from the Stoics during Cicero's visit in 79, he does not mention any, though he was exceedingly anxious to meet the old anthropologist Poseidonius when his party arrived at Rhodes.

The Athenian Stoa had in recent years tried an innovation rather different from the Epicurean one - it has even been called a trahison des clercs - in an attempt to capture one of the selling elements of the current emotional climate. Diogenes of Seleucia, the "Babylonian" sent on the second-century embassy to Rome, had tried to modify the doctrines of astrology sufficiently to give them the implied support of Stoicism: under his leadership the school offered the Hellenistic, world as it succumbed to Rome, the excuse that astral determinism absolved it of any real failure. ${ }^{20}$ His successor Panaetius (who was himself unconventionally skeptical) rejected the entire idea, ${ }^{21}$ though his absences in Rome prevented his forcing a clear consensus, or his quelling a parallel developing interest in naturopathic or sympathetic magic. ${ }^{22} \mathrm{His}$ successors Mnesarchus and Dardanus (under whom the Stoa may have ridden out the Sullan siege), perhaps steered the school toward a compromise, ${ }^{23}$ but not before Panaetius' brilliant student Poseidonius had begun to steal their thunder to advertise his own center in Rhodes.

Stoics were still regularly honored by the city (they made very safe teachers for the ephebeia) ${ }^{24}$ and Cicero did later find himself impressed by the scholarch of $50 .^{25}$ It is this Dionysius that his Tusculans assumes a typical travelling Roman student will have heard in the Athens of those years, and calls the time "princeps Stoicorum." But other cities now usually outshone the Athenian version of the Stoa. Besides Rhodes, there were what remained of the Pergamene school (where Cato found Athenodorus Cordylion), and then there were the great centers like Tarsus in the East. Panaetius and Poseidonius in their years attached to Roman noblemen had done their job too well. ${ }^{26}$ Stoic masters were now in abundant supply in Rome itself and did not generally require a suspicious eye from the government.

The Athenian Stoa, like the Garden or the "pocket Academy" now run in "downtown" Athens by Charmadas, was one of the "newer" schools, and

20. Cicero, De Divinatione ii, 90.

21. Cicero, De Divinatione ii, 88 (on the contrary position of Panaetius).

22. Cf. Dodds, Greeks and the Irrational, 246-247.

23. J.-L. Ferrary, Philhellénisme et Impérialisme: Aspects Idéologiques de la Conquête Romaine du Monde Hellénistique, de la Seconde Guerre de Macédoine à la Guerre Contre Mithridate [Philhellenism and Imperialism: Ideological Aspects of the Roman Conquest of the Hellenistic World, from the Second Macedonian War to the War Against Mithridates] (Rome: École française de Rome, 1988), 449-453.

24. Pausanias, IX, xv. H.B. Gottschalk, "Notes on the Wills of the Peripatetic Scholarchs" in Hermes, (1972), 316-17. Ferrary, Philhellénisme et Impérialisme, 457-458.

25. Plutarch, Cato Minor, 4. Cicero, De Offic. II, xxiv, 86.

26 W.W. Fowler, Social Life at Rome in the Age of Cicero (New York, 1915), 114-116, $332-338$. 
none of these had for the newly enthusiastic Romans arriving in Greece quite the same auctoritas, or antique feel, or even tourist value, as the old ones. The Stoa might have billed itself as the only exception since its precepts fit so well with Roman mores, but this advantage it took a while to realize. Its teachings appealed most to a man who was forced to remain at his job in a world of chaos, injustice, and tyranny. Thus, the appeal for an Athens weary of political turmoil was understandably something far more like our modern expectation, but at first this sold very poorly to young Romans "on the make." It was only the prolonged effects of Civil War-weariness that saved the Stoa, and made it the refuge of a generation of ruined political "players".

That point of weariness, for most young Romans, had not quite come yet in the first decades after the Mithridatic siege. Moderns cannot perhaps read about this world without sensing, like the slow rising of a storm on the far horizon of the mind's eye, that an almost fatal cataclysm was about to engulf the Roman Republic. Even if we suspend our historical knowledge of the coming narrative, we still cannot help smelling the burning in the air. Clever, hungry young men like Cassius, and Cato, and Caelius Rufus, who as children had grown up playing devious, amoral games of politics, arrest, and litigation, ${ }^{27}$ seem to have been nearly, tragically blind to the firestorm they were building and fueling. They went on playing as grown men, when real laws and cultures had become the stakes, each one of them utterly sure in his heart of hearts that he could ride the whirlwind.

Before all this became plain, the Stoa's earliest appeal in Cicero's age was, I think, its sophisticated style and its setting. The old Athenian Agora had become a sort of "college campus" for the Stoics ${ }^{28}$ - "Old Quad" to the south, "New Quad" to the north. Through the forest of pedestalled statues in between strolled a crowd of bright young men who wanted to seem above politics, and a crowd of sad older men who had found themselves in time beyond it, or outside it, or crushed beneath it.

27. Cf. for example the first chapter of Plutarch's Cato the Younger, perhaps the most authentic of Plutarch's glimpses of Roman childhood during these years, esp. the story of typical young Roman boys playing, while their parents are busy with dinner, at games of accusation and arrest. Such men, once grown up, went on playing the same games with real lives, but the flavor of a game still hung, for many, round even the deadliest episodes. The letters of Caelius Rufus to Cicero about the political throes of the dying Republic (all in Ciceros ad Familiares, bk. viii). The best short study of Caelius--the brilliantly wasted career, the sheer number of like bright, restless young men playing on the brink of the volcano--is still in Fowler, Social Life, 126-134. See also J. J. Clauss, "The Ignoble Consistency of M. Caelius Rufus," Athenaeum, vol. 1xxviii fascicle II (1990).

28. See note 63 on the Sanctuary of Ares and the Agora in general in Peter Levi's (Penguin) edtn. of Pausanias (Harmondsworth, 1984), vol. 1, p. 29. Augustus seems to have taken the character of the place as "campus and quad" really to heart; his building here is all aimed, if I understand it rightly, at the young men of senatorial class who spent their formative "college" years learning in the stoas and walking beneath the grove of columns here. The temple of Ares (Augustan sanctuaries of Mars are nearly always dedicated to Mars Ultor--"the Avenger," not aggressor) was a genuine piece of fifth century work, discovered by antiquarian interest (perhaps near Acharnae) and placed where it could serve as commentary on the public and moral nature of the technai learned, and its service in the new empire. With such a nuance it must have formed an interesting and thought-provoking counterpoise to the Altar of Pity. The two lay side by side 
But all this sad accumulation of emotional detail - as rough as times had genuinely been for the city of Athens, hardly adds up to the bleak picture Athenion and Aristion, the "akademic-epicurean" rebels tried to paint as they goaded the city into its first century hostage crisis, or that modern scholars seem to imagine, in their disappointment with Roman Athens, now. Athens was, and in particular its post-Akademe schools were, far from being silent. They made the place in "gestalt" an elegant, half-real, half intellectual urban ecology of the mind, that shouldered its image of thoughtful life centrally into the dreams, arguments and misgivings educated Romans had about the era they lived in, and where it was going. They studied in Athens and, when they needed to take stock or re-center themselves, came back to it. The place was a great one for being seen, or soaking in the "atmosphere" of philosophy, and while Plato's Academy was the iconic glory, it was generally the other schools and their presence in the flavor of the city that made most of the real contributions, in practical culture and human careers.

The old buildings of the classical Athenian democracy looked down all round like the ghosts of a purer era, whatever violence or deceit they might have seen in their day, they had seen not just brilliance, but a brilliance in which competing, contesting and mutating points of view could be melded into an on-going cultural dialogue. The symbol (a very un-Platonic symbol) was perhaps the highlight of the northern corner of the "quad," where across the long porticoes of the sunniest stoas fell a shadow where the Altar of the Twelve Gods had once dominated bustling, quarrelling political assemblies of the classical city. Instead there was now, perhaps appropriately to both the anxiety and diversity of the new world, an Altar of Pity. ${ }^{29}$

This crowded, intimate landscape of statues and dedications (the only such space over which Pausanias lingers longer is Olympia) threw a shade across the porches of the Stoa, and the old Agora round about it. By this point, perhaps in reaction to what Sulla had done, the Romans in their better moments shaded the city of Athens and schools from the heat and danger of their own destructive ambition, and from the last violence of the crumbling Hellenistic world. They often returned to Athens when their own power games disintegrated. Whether from nostalgia like Cicero's, or a desire like that of Brutus simply to disappear into a lost, calm world imagined from student days, Roman after Roman came back, and for a time, Athens ended by sheltering them.

29. Pausanias, I, xvii, 1. The feeling is well- expressed in the brief description--a sort of testimony to the chastened graciousness of the later Athens. Another echo is in Statius' Thebaid, XII, 481-509. (See also Levi's note, loc. cit. of the Pausanias passage, and H.A. Thompson's note in Hesperia, vol. XXI, (1952). It is significant, in light of its relation to Augustus' Temple of Ares (its neighbor--see n. 2, p. 10) that the nearest reflection now remaining of its artistic style and religious feeling is the Ara Pacis Augustae in Rome. 


\section{Bibliography}

Athenaeus, Deipnosophistae.

Badian, E. "Rome, Athens, and Mithridates." In American Journal of Ancient History, 1(1976).

Badian, E. Studies in Greek and Roman History. Oxford: Basil Black- well, 1964.

Cicero, the letters on specific schools and scholars, letters discussing the same from Atticus, Caelius Rufus, Cicero's sone, etc., as well as side discussions in (among others) De Divinatione, De Officiis, De Finibus

Cronert, W. "Der Epikurer Philonides." Sitzb. Berl. Ak. (1900).

Diogenes Laertius

Dodds, E.R. Greeks and the Irrational. Berkeley: University of California Press, 1951.

Ferguson, W.S. Hellenistic Athens: an Historical Essay. London, 1911.

Ferrary, J.-L. Philhellénisme et Impérialisme: Aspects Idéologiques de la Conquête Romaine du Monde Hellénistique, de la Seconde Guerre de Macédoine à la Guerre Contre Mithridate [Philhellenism and Imperialism: Ideological Aspects of the Roman Conquest of the Hellenistic World, from the Second Macedonian War to the War Against Mithridates]. Rome: École française de Rome, 1988.

Fowler, W. W. Social Life at Rome in the Age of Cicero. New York, 1915.

Gottschalk, H.B. "Notes on the Wills of the Peripatetic Scholarchs." In Hermes (1972).

Lewis, D. M. "Two Days." In Classical Review (Dec., 1969).

Pausanias, Bks I, II, in particular the anthropological walk through the Agora of his era. (Fraser's edtn. In the Loeb is the classic, but I would add a special recommendation of the notes in Peter Levi's Penguin edtn. (Harmondsworth, 1984)

Raubitschek, A.E. "Phaedros and his Roman Pupils." In Hesperia, no. 18(1949).

Rawson, E. Intellectual Life in the Late Republic. London, 1985. 
